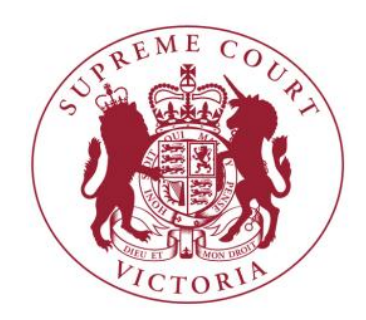

\title{
ASSESSORS IN THE KILMORE EAST BUSHFIRE PROCEEDING
}

\begin{abstract}
SIMON MCKENZIE*
This paper, the fourth and final in a series on the management of expert evidence during the Kilmore East bushfire proceeding, considers the use of assessors. During the proceeding, Justice J. Forrest appointed assessors to assist him with some of the most complex aspects of the expert evidence. The assessors played a significant role in the proceeding, helping to guide the expert conferences, sitting with Justice J. Forrest during the largest concurrent evidence session and participating in the examination of the experts. This paper is based on interviews conducted with some of the judges, barristers, solicitors and experts involved in the proceeding, and it records their reflections on whether the use of assessors was valuable. It appears that the use of assessors was a success, and all the participants interviewed regarded them as being beneficial to the trial. They were satisfied that the method of selection adopted by the Court was appropriate. The assistance the assessors provided Justice J. Forrest with understanding the expert evidence was essential, and having people capable of engaging in technical dialogue with the experts while they were giving evidence was useful. This paper suggests that the appointment assessors should be considered in future cases of similar complexity to help the trial judge deal with very difficult expert evidence.
\end{abstract}

\section{CONTENTS}

I. Introduction 2

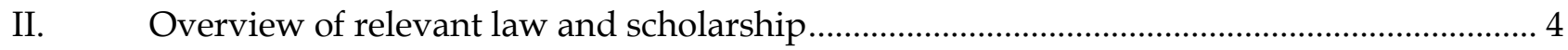

III. The decision to appoint assessors in the Kilmore East bushfire proceeding......................... 8

\footnotetext{
* BA, LLB (Hons) (Tas); Senior Fellow (Melbourne Law Masters) and PhD Candidate at the University of Melbourne. The support of Justice Rita Zammit and Justice Jack Forrest was invaluable in carrying out this research project. In addition, the assistance and advice of Gary Cazalet at the University of Melbourne as well as Stuart Moran and Katrina Chow at the Supreme Court of Victoria are gratefully acknowledged. The Supreme Court of Victoria funded this research.
}

This paper was published on 13 April 2016. 


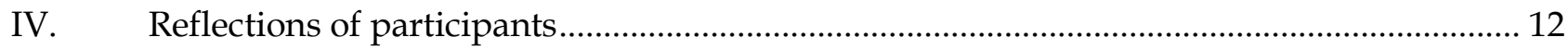

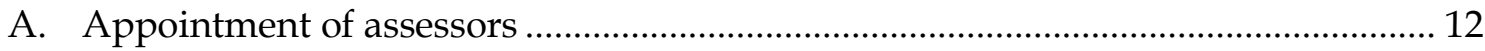

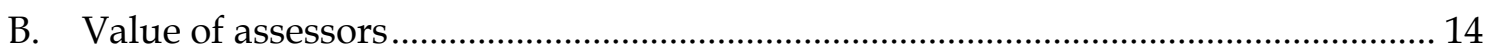

C. Assessors and the expert conferences ……………………………………………..... 16

D. Interaction between the assessors, the Court and the parties ....................................... 17

E. Abdication of judicial power ..................................................................................... 20

V. Concluding Remarks .............................................................................................. 21

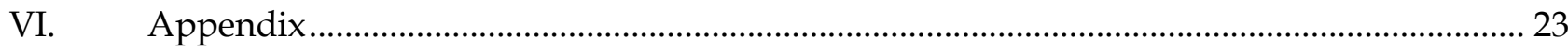

A. Section One: View from the Victorian bench ……………………………………….... 23

1. Distinction between Assessors and Special Referees............................... 23

2. Assessors as an abdication of judicial power........................................... 24

B. Section Two: Methodology ………………………………………………………... 25

\section{INTRODUCTION}

The case of Matthews v SPI Electricity Pty Ltd (the 'Kilmore East bushfire proceeding') required the Victorian Supreme Court to confront highly complex expert evidence. The trial judge, Justice Jack Forrest decided it was necessary to appoint two assessors to assist him with the most complex parts of the evidence. These assessors played a significant role in the proceeding: they helped guide the most complex expert conference by providing questions to the experts while they were in conference; they sat with Justice Forrest during the largest concurrent evidence session and participated in the examination of the experts; and they were available to Justice Forrest when writing the judgment (even though the case ultimately settled). They were an essential part of the Court's response to the challenge posed by the voluminous and highly technical expert evidence.

This is the fourth and final paper in a series about the management of expert evidence in the Kilmore East bushfire proceeding. It considers the role of assessors in the proceeding, and records the perspectives of the participants on the assessors' impact on the proceeding, and the value of their appointment. The first section provides an overview of the use of assessors in common law jurisdictions, and some of the advantages and disadvantages of their appointment. This research shows that the value of assessors is widely recognised, but that there are fears that their use might amount to an abdication of judicial power. As such, some have argued that tight limits should be placed on their interaction with the judge and that there should be complete transparency with any information they provide by revealing that information to the parties in full. However, Australian judges and scholars have tended to be more relaxed than their overseas peers about the 
interaction between assessors and judges, comparing it to the relationship between associates and judges, or between judges.

The paper goes on to explain how the assessors were used in the Kilmore East bushfire proceeding, summarising how Justice Forrest determined they were required, and how Associate Justice Zammit went about selecting them. It then addresses the experience of the participants, and their reflections on four issues: the appointment of the assessors; the interaction between the assessors and the experts at the expert conferences; the role the assessors played in the concurrent evidence sessions; and finally, whether the appointment of assessors could amount to an abdication of judicial power.

This material was gathered through interviews conducted with the judges, and some of the barristers, solicitors and experts involved in the proceeding. Even though the plaintiff was initially opposed to the appointment of assessors, these interviews show that in hindsight the appointment of assessors was one of the least controversial aspects of the proceeding. All parties were ultimately convinced they were useful as they assisted Justice Forrest in managing the expert evidence. They were satisfied that the limitations placed on the interaction between the judge and assessors were appropriate, and that the use of assessors did not amount to an abdication of judicial power. The interviews indicate that using assessors can be a convenient way of dealing with complex expert evidence. It helps the judge cope with the difficult task of making sense of technically complex expert evidence in cases like the Kilmore East bushfire proceeding, and therefore to better exercise his or her judgement.

There is an appendix to this paper to ensure that the reader can have a more complete picture of the use of assessors. The first section sets out the views of Victorian judges who were not involved in the Kilmore East bushfire proceeding about the use of assessors, with a particular focus on some of the concerns raised in the literature as well as the issues that arose in the proceeding. The judges recognised assessors could be useful in some circumstances, and that it was a more appropriate mechanism than a special referee when the relevant expert evidence was at the heart of the determination of liability. They did not think that appointing an assessor, properly handled, would amount to an abdication of judicial power. The second section sets out the methodology used for the paper, including an acknowledgement of some of the limitations of this research. 


\section{OVERVIEW OF RELEVANT LAW AND SCHOLARSHIP}

Common law courts have been using assessors to assist judges with highly specialised and technical evidence and testimony for many years, particularly in admiralty cases. ${ }^{1}$ In Victoria, the power to appoint an assessor is provided by s 77 of the Supreme Court Act 1986 and s 65M of the Civil Procedure Act 2010. Section 65M states that a court can appoint an expert to "assist the court" and to "inquire into and report on any issue in a proceeding". Section $65 \mathrm{M}(3)$ sets out a number of factors the court must consider in making such an order:

(3) In making an order to appoint a court appointed expert, the court must consider -

(a) whether the appointment of a court appointed expert would be disproportionate to -

(i) the complexity or importance of the issues in dispute;

(ii) the amount in dispute in the proceeding;

(b) whether the issue falls within a substantially established area of knowledge;

(c) whether it is necessary for the court to have a range of expert opinion;

(d) the likelihood of the appointment expediting or delaying the trial;

(e) any other relevant consideration.

Even though it uses the word "expert", this provision encompasses the appointment of an assessor. Justice Heerey of the Federal Court of Australia neatly explained the role of the assessor, and its basic limitations, in his decision in Genetic Institute Inc v Kirin-Amgen Inc (No 2)2:

An assessor is to assist the judge, both in hearing and trial and/or in determination of any proceeding. The judgment in the case, the exercise of the judicial power, remains that of the judge. ${ }^{3}$

Assessors have a different role from other court appointed expert witnesses, such as special referees. The Australian Law Reform Commission ("ALRC") set out the differences between assessors and expert witnesses:

- Assessors are not sworn and cannot be cross-examined;

- Their advice is usually given to the judge in private and is only disclosed to the parties at the discretion of the court and at the end of the case in the judgment;

\footnotetext{
1 See Australian Law Reform Commission, Review of the Federal Civil Justice System, Report 89 (2000), 13.144-5. Also see Justice James Allsop, 'The judicial disposition of competition cases' (2010) 17 Competition \& Consumer Law Journal 248-9.

2 (1997) 78 FCR 368.

${ }^{3}$ Ibid 371.
} 
- It is "simply an expert available for the judge to consult if the judge requires assistance in understanding the effect or meaning of expert evidence". ${ }^{4}$

The judge sets the limits on the participation of the assessors in the proceedings, and it differs from case to case. Assessors have been permitted to comment in open hearing about any evidence raised, 5 and at other times they have been given the responsibility of making inquiries and reporting back to the court on particular issues. ${ }^{6}$ They are someone the judge can confer with about the complex and technical evidence that comes before the court.

The value of appointing assessors in some circumstances is widely recognised. It assists a judge in dealing with difficult expert evidence in the trial. The ALRC explained that:

Technical evidence needs to be presented in a comprehensive, clear way, [but] the examination and cross-examination processes and the sequential presentation of evidence does not always assist this aim. One response to this difficulty is for the court to appoint an assessor or other expert assistant to advise the judge or other decision maker. ${ }^{7}$

This is also recognised in case law. In the English case of Richardson $v$ Redpath, Brown $\mathcal{E} C_{0}^{8}$ Viscount Simon explained the value that assessors can provide to the Court. He said that:

[Treating an assessor] as though he were an unsworn witness in the special confidence of the judge, whose testimony cannot be challenged by cross examination and perhaps cannot even be fully appreciated by the parties until judgment is given, is to misunderstand what the true functions of an assessor are. He is an expert available for the judge to consult if the judge requires assistance in understanding the effect and meaning of technical evidence. He may, in proper cases, suggest to the judge questions which the judge himself might put to an expert witness with a view to testing the witness's view or to making plain his meaning. The judge may consult him in case of need as to the proper technical inferences to be drawn from proved facts, or as to the extent of the difference between apparently contradictory conclusions in the expert field. It would seem desirable in cases where the assessor's advice, within its proper limits, is likely to affect the judge's conclusion, for the latter to inform the parties before him what is the advice which he has received. ${ }^{9}$

\footnotetext{
${ }^{4}$ Australian Law Reform Commission, Review of the Federal Civil Justice System, Report 89 (2000), 13.147.

${ }^{5}$ See Beecham Group Ltd v Bristol-Myers Company (No 2) [1980] 1 NZLR 185.

${ }^{6}$ Australian Law Reform Commission, Review of the Federal Civil Justice System, Report 89 (2000), 13.151.

7 Ibid 13.139.

8 [1944] AC 62.

${ }^{9}$ Ibid 70-1.
} 
In Genetic Institute Inc $v$ Kirin-Amgen Inc (No 2)10, Heerey J said that in helping resolve disputes between experts, who "can contest issues with the enormous advantage of a lifetime of experience in the discipline", the judge was likely be assisted by an assessor. ${ }^{11} \mathrm{He}$ said that:

No doubt the judge could reach a decision without such assistance, but that is not the point; [the relevant provision] does not posit a criterion of total judicial inadequacy as a pre-condition of appointment of an assessor. It is simply a question of whether the judicial task can be better performed. ${ }^{12}$

Justice James Allsop, then President of the New South Wales Court of Appeal, has expressed the view that a private consultation between the judge and the assessor could be very helpful in competition law cases:

A degree of assistance in the interpretation of expert evidence would often be of significant assistance to the judge making it likely that time taken to resolve cases would be shorter and the physical energy demanded of judges to command the facts would be relieved. If one contemplates the size of many competition cases, the sometimes platoon-like manning of each side with expert witnesses, solicitors, junior counsel, senior counsel and the recognition that one judge will decide the case at first instance, leads one to conclude that it is often quite unfair to expect a judge to be able to deal with these without some degree of assistance. ${ }^{13}$

The ALRC echoed this point, noting that while judges can specialise in particular categories of cases, they can still face technical evidence of enormous complexity in their area of legal expertise. ${ }^{14}$

Courts in other jurisdictions in Australia also have the power to appoint assessors to assist with complex evidence. ${ }^{15}$ Despite this being available to judges, Justice Allsop comments that he has "never seen the [relevant Federal Court] order used". ${ }^{16}$ Justice Allsop says the "tool of the assessor, if carefully and thoughtfully used, could be of great utility to the modern judge hearing a case about any expert discipline" ${ }^{17}$

10 (1997) 78 FCR 368.

11 Ibid 373.

12 Ibid 373.

${ }^{13}$ Allsop, 'The judicial disposition of competition cases', above n 1, 250.

14 Ibid 13.141.

${ }^{15}$ See for instance Order 34B of the Federal Court Rules which allows for the Court, with the consent of the parties, to appoint an expert assistant to assist the judge on any issue of fact or opinion.

16 Allsop, 'The judicial disposition of competition cases', above n 1, 243.

17 Ibid 249. 
There is a concern that the assessor might have too much influence over the judge, and express views that the parties might wish to challenge but have no opportunity to do so. ${ }^{18}$ It was mainly for this reason that the Ireland Law Reform Commission ("ILRC") recommended against increasing the use of assessors in litigation, finding it was unlikely to be beneficial. ${ }^{19}$ The ILRC was concerned that the parties would not be able to challenge the information provided by the assessor, and that there was no way for the parties to form a view as to whether the assessor was undertaking their role with sufficient independence. ${ }^{20}$ The costs of the proceeding could also substantially increase by adding another expert, as an assessor, to the trial. ${ }^{21}$ The ILRC explained its preferred approach:

It is submitted that a better way to increase the knowledge of the judiciary in technical or scientific matters is to encourage members of the judiciary to attend continuing professional development courses in such areas, rather than the use of specialist advisors in individual cases who remain unaccountable to either party or the court.

As mentioned in Chapter 1, in the patent infringement case Kirin-Amgen Inc and Ors v Hoechst Marion Roussel Ltd and $\mathrm{OrS}^{22}$ the House of Lords were, with the consent of the parties, given a series of seminars in camera prior to the case by a Professor of Biochemistry at Oxford University to explain the relevant aspects of recombinant DNA technology.

This, it is submitted, is a preferable approach to the use of assessors, as the information given in a series of seminars is likely to be generalised information on the subject and not specifically applied to the facts of the case at hand so will thus avoid the taint of bias of the person providing the expert information. ${ }^{23}$

The IRLC is not alone in preferring an approach that severely limits the interaction between the judge and any assessor. In the English Admiralty case of The Bow Spring $v$ The Manzanillo II, ${ }^{24}$ the Court of Appeal of England and Wales held that principles of natural justice, as found in both the common law and the European Convention on Human Rights, required a transparent interaction between judge and assessor. ${ }^{25}$ As the parties should have the opportunity to know the evidence on which the case is decided, which includes material put by the assessor before the judge, "any

\footnotetext{
18 Australian Law Reform Commission, Review of the Federal Civil Justice System, Report 89 (2000), 13.152.

19 Ireland Law Reform Commission, Consultation Paper - Expert Evidence, CP52-2008 (2008), 5.330.

20 Ibid, 5.327-30.

21 Ibid.

22 [2004] UKHL 46.

${ }^{23}$ Ireland Law Reform Commission, Consultation Paper - Expert Evidence, (2008) CP52-2008, 5.331-3.

24 [2005] 1 Lloyds Rep 1, [57]-[65].

25 [2005] 1 Lloyds Rep 1, [57]-[65].
} 
consultation between the assessors and the court should take place openly as part of the assembling of evidence." 26 In practice, this means that both the questions that the assessors are asked, as well as the answers they give, must be disclosed to the parties.27

Justice Allsop thought that this approach was not necessary to protect the rights of the parties. He said that:

$\ldots$ as long as it is clear that the task of consultation and its extent is to be disclosed, it is difficult to see why the judge should not have the availability of the assessor out of court as well as in court. The scope and difficulty of the evidence in many cases, $[\ldots]$ is such that a single judge is often left with a vast task which can take months to unravel. The availability of a consultative agency such as assessor would be of considerable assistance. It is not as if judges do not talk to others. ${ }^{28}$

Justice Heerey made a similar point in Genetic Institute Inc v Kirin-Amgen Inc (No 2)29, noting that "[i]n exercising judicial power, a judge is routinely assisted by persons who are not judges: counsel, solicitors, witnesses, the judge's associate and secretary and other Court staff." 30 Judges are able to manage the assistance offered by other people in a way that does not delegate their judicial authority. The ALRC was also convinced that courts should use assessors more often, and that they could play a helpful role in complex proceedings. ${ }^{31}$ The Victorian Law Reform Commission also recommended giving the power to the Court to appoint experts to assist the court as it "may be useful" in some circumstances. 32

\section{THE DECISION TO APPOINT ASSESSORS IN THE KILMORE EAST BUSHFIRE PROCEEDING}

Justice Forrest decided that he would appoint assessors to assist him with some of the expert evidence $^{33}$ after a briefing by two experts on the critical scientific concepts regarding the cause of the failure of the conductor. ${ }^{34}$ He decided that he would be unable to understand properly the expert material without the assistance of assessors during the hearing of the evidence.

\footnotetext{
26 Ibid [59].

27 Ibid [61].

${ }^{28}$ Allsop, 'The judicial disposition of competition cases', above n 1, 249-50.

29 (1997) 78 FCR 368.

30 Ibid 371.

${ }^{31}$ Australian Law Reform Commission, Review of the Federal Civil Justice System, Report 89 (2000), 13.161.

32 Victorian Law Reform Commission, Civil Justice Review: Report (2008), 512.

33 Ruling No 19 [2013] VSC 180 (18 April 2013).

34 Ibid [2].
} 
The plaintiff had submitted that the judge would be able to understand the evidence about scientific and engineering concepts with the assistance of the expert witnesses. Justice Forrest did not accept this submission, explaining that he was not confident that he would be able to understand all the evidence, or resolve any disagreement between experts without assistance. ${ }^{35} \mathrm{He}$ considered whether he should refer the relevant matters to a special referee, or sit with assessors. All the parties were against the appointment of a special referee. ${ }^{36}$ While his Honour noted that this would not preclude him from appointing a special referee (which would provide the Court with a finding about what expert evidence should be accepted), he nevertheless decided against it for a number of reasons:

1. The cause of the failure of the conductor, which would be the issue that the special referee would assist with, was critical to the case. ${ }^{37} \mathrm{He}$ said in such circumstances, "I should be wary of abdicating responsibility for the determination unless absolutely persuaded as to the necessity of that course". ${ }^{8}$ His Honour preferred the alternative course of seeking the assistance of an assessor.

2. It was likely that issues of reliability and credit would be one of the factors in assessing the evidence of the expert witnesses, and this was an assessment better made by a judge than a legally unqualified expert. ${ }^{39}$ In addition, it could require an assessment of the evidence given in the trial outside the expert evidence session. ${ }^{40}$

3. The question to be resolved would be a hybrid of legal and factual issues and a special referee would have to understand both the factual situation and legal concepts of breach and causation. ${ }^{41}$

4. The appointment of a special referee would cause further delay as the proceedings would have to wait for the referee to provide his or her report. ${ }^{42}$

5. His Honour held that the process by which the report of the special referee was adopted could pose a real challenge to the Court. He was concerned that he might not be able to understand the calculations and reasoning underpinning any conclusions, and that it

\footnotetext{
35 Ibid [15].

36 Ibid [21].

37 Ibid [23].

38 Ibid.

${ }^{39}$ Ibid [24].

40 Ibid.

41 Ibid [25].

42 Ibid [26].
} 
would therefore be very difficult to assess the report, particularly in the face of an attack on the report by either party. ${ }^{43}$

Instead, Justice Forrest decided that assessors should be appointed to assist him. He held that they would enable him to "seek advice and guidance on scientific and engineering points which are beyond my ken" and was certain that "the judicial task can be better performed with such assistance and the likelihood of a fair determination enhanced." 44 He delegated the selection of the assessors to Associate Justice Zammit, as she had been managing the expert conferences on the failure of the conductor and so was well placed to manage the appointment of assessors to assist with the same issues. 45

The assessors were chosen in close consultation with the parties. Associate Justice Zammit asked each of the parties to submit a list of names to the Court. She explained that:

Each party had an opportunity to present their six names and they basically said this is who we recommend first, second, third and why we think this is the best person given the issues in this case.

[...] Their concerns were obviously, I think, the same as the Court's: having the right people with the right experience and background. ${ }^{46}$

From this list of names, Associate Justice Zammit worked with the parties to identify who was conflicted and so could not be appointed, and who was not available to participate in the proceeding due to other commitments, before settling on the two assessors that Justice Forrest went on to appoint in October 2013. The costs of the assessors were paid by the plaintiff, the first defendant and the second defendant in equal shares. ${ }^{47}$

After they were appointed, Justice Forrest clarified what their role would be in the proceeding:

The primary role of the assessors is to assist the court in understanding the evidence of the experts. Applying the [Civil Procedure Act], combined with the principles of natural justice and guidance from the cases I have referred to, I set out below the scope of the role of the assessors in this case:

a) The assessors' role is to assist the judge. The decision is for the judge alone.

b) The assessors will sit with me during the concurrent evidence sessions. If they wish, they may question the experts (or counsel) in this context. Such questioning however will be

\footnotetext{
43 Ibid [27-28].

44 Ibid [34].

45 Ibid [37].

46 Interview with Associate Justice Zammit (13 August 2014, Supreme Court of Victoria, Melbourne).

47 Order made 25 September 2013 and 3 October 2013.
} 
limited to clarification of the evidence; that is, where they consider the evidence to be ambiguous, unclear, or incomplete.

c) I may consult with the assessors while sitting if I find a point of evidence unclear and seek their immediate input as to an appropriate or useful inquiry to make.

d) I will consult with the assessors whilst in chambers on matters raised by the experts in their oral evidence and in their individual and joint reports. This may include advice as to any questions the assessors think I should ask counsel or the experts in order to determine the questions at hand.

e) I will seek the guidance of the assessors on technical matters upon which I lack the requisite knowledge to understand without qualified assistance. This may include "lessons" on matters fundamental to, for example in this case, fracture mechanics or vibration.

f) If the assessors raise a theory or opinion that has not previously been identified by the parties, I will discuss this with counsel.

g) The assessors may from time to time provide me with advice on matters over which there is a dispute between the experts. Such advice is not binding and the determination of a particular issue rests with the judge.

h) I anticipate that I will consult with the [assessors] immediately after the conclusion of the concurrent evidence session and, from time to time, while drafting the judgment. This is likely to include seeking confirmation from them that I have properly understood the meaning of the expert evidence of conclaves 1, 3 and 4. I repeat, however, that their role is confined to providing advice and ensuring that I have comprehended the evidence given. I also repeat that the decision on these issues is mine and mine alone. ${ }^{48}$

This ruling ensured that the parties fully understood the limitations that Justice Forrest placed on his interaction with the assessors.

The assessors' first interaction with the experts was drafting questions for one of the expert conferences. ${ }^{49}$ This conference was discussing part of the evidence that would be heard by the Court in one of the concurrent evidence session where Justice Forrest was going to be assisted by the assessors sitting alongside him. The questions were provided to the experts on the final day of the conference, and the experts were then instructed to work on them individually, to give yes or no answers, and if they wanted to they were able to explain their answers in the limited space

\footnotetext{
48 Ruling No 32 [2013] VSC 630, [27].

${ }^{49}$ Interview with Justice J Forrest (8 August 2014, Supreme Court of Victoria, Melbourne).
} 
provided. 50 The aim of the process was to gain a manageable overview of the individual opinions of the experts as opposed to their collective view. ${ }^{51}$ They participated in the concurrent evidence session by asking questions of the experts.

Aside from the questions provided at the conference and posed during the concurrent evidence session, the assessors had no real interaction with the parties or the experts. Legal counsel did not talk to them in court, the experts did not interact with the assessors outside of the conference and concurrent evidence session, and the assessors' interactions with Justice Forrest remained private.

\section{REFLECTIONS OF PARTICIPANTS}

\section{A. Appointment of assessors}

Justice Forrest said he decided to appoint assessors once he was satisfied that he "could not manage the case" without the assistance of engineering experts with knowledge of the most complex parts of the expert evidence. 52 He said the correctness of this decision was borne out by the evidence that emerged from the relevant concurrent evidence sessions. The experts told him the information produced by the case could have been the subject of "three or four PhDs". ${ }^{53}$ It is difficult to see how he would have handled this level of complexity, as well as all the other issues the trial brought up, without assistance.

Justice Forrest made an order appointing Associate Justice Zammit to select the assessors, which she did with the input of the parties. She said that the concern of the Court was to ensure that the assessors appointed "understood their role" (in providing advice rather than making decisions) and had the "requisite knowledge to be able to assist the Court". ${ }^{4}$ It was also important that the assessors had "personalities that would be flexible enough and accommodate what was a fairly unusual sort of setting." 55 A particular problem that arose in the Kilmore East bushfire proceeding was that part of the expert evidence the assessors would be assisting with involved a number of different areas of expertise. Associate Justice Zammit said that two assessors were appointed

\footnotetext{
50 Ibid.

51 Ibid.

52 Ibid.

53 Ibid.

54 Interview with Associate Justice Zammit, above n 46.

55 Ibid.
} 
because it was clear that no one assessor was going to be able to "adequately traverse the range of issues". .56

Her Honour said involving the parties made the process much more straightforward, and yielded good results:

I could never have put the list of names together. [...] [T] he parties [...] had access to the experts who knew who the leaders [in their fields] would be. [...] I felt that they [the experts] knew both locally and internationally who could deal with the sorts of issues that they had to deal with. [I]n terms of time and finding these people, it would have been a needle in a haystack for me. We were looking for people with very particular skill sets and [the parties] were able to effectively do all the work for the Court, pull together all their resumes, provide me with some of their published papers, put a summary of it together. ${ }^{57}$

Justice Forrest said the way Associate Justice Zammit handled the appointment of the assessors was "totally appropriate": the parties had an opportunity to participate in the process, and the assessors appointed were very helpful to the Court. 58

The legal practitioners were also satisfied with how the assessors were selected. One solicitor said the process was "pretty sound", particularly as everyone had an opportunity to put forward names. ${ }^{59}$ The other said the process was "appropriate". ${ }^{60}$ One barrister said it was essential for the Court to select the assessors, but he thought it was sensible to base this choice on lists provided by the parties. He said:

I thought the Court was very good at selecting what I'll describe as a qualitative expert and a quantitative one. The parties set out the areas over which the assessors should have a background, sent out $\mathrm{CVs}$, the court made its selection. I thought it was a very useful idea. ${ }^{61}$

There was some suggestion that the Court could have appointed assessors earlier in the proceeding. ${ }^{62}$ Associate Justice Zammit said greater "front end" involvement could have "truncated" the proceeding. In particular, they would have been able to assist with the setting of

\footnotetext{
56 Ibid.

57 Ibid.

58 Interview with Justice J Forrest, above n 49.

${ }^{59}$ Interview with solicitor involved in proceeding (20 February 2015, Melbourne) ('Interview with solicitor $\left.\mathrm{A}^{\prime}\right)$.

${ }^{60}$ Interview with solicitor involved in proceeding (9 June 2015, by letter) ('Interview with solicitor B').

${ }^{61}$ Interview with barrister involved in proceeding (Afternoon of 24 February 2015, Melbourne) ('Interview with barrister $\mathrm{B}^{\prime}$ ).

62 Interview with Associate Justice Zammit, above n 46.
} 
the agendas for the expert conferences, a task requiring substantial technical expertise. ${ }^{63}$ While the experts also had that technical expertise, the assessors may have been more efficient as they were able to be more responsive to the needs of the Court. ${ }^{64}$ They would have been able to assist the judge to determine what items were likely to be helpful in advancing the issues and to stay focussed on the critical issues that had to be resolved. ${ }^{5}$ Similarly, one barrister said appointing assessors earlier in the case was "certainly [...] worth considering in an appropriate case" to help manage complex expert evidence. In particular, he thought the impartial expertise would have been very useful to assist the judge in dividing up the experts into the various expert conferences appropriately. ${ }^{66}$

\section{B. Value of assessors}

The interviews with Justice Forrest and Associate Justice Zammit give a fuller understanding of the role the assessors played in the proceeding. Justice Forrest said each assessor had a different and complementary style and that they "assisted immeasurably in understanding the expert evidence." ${ }^{67}$ He explained:

Each was extraordinarily helpful in terms of briefings prior to starting the expert evidence session, and [we] would spend a day to a day-and-a half going through the material and with the assessors using whiteboards [and] digital screens to assist me in understanding it. In terms of the actual trial, we conferred at virtually every break and prior to and after the core sitting days, and then on days when the court wasn't sitting we had the opportunity to talk.

$[\ldots]$

[After the two assessors left Melbourne] we then had several Skype sessions with [them]; one who was in Oxford and the other in Sydney. Essentially, those sessions were to endeavour to formalise [my] thoughts on some of the significant issues concerning the concurrent evidence session and [my] conclusions. ${ }^{68}$

\footnotetext{
63 Ibid.

64 Ibid.

65 Ibid.

${ }^{66}$ Interview with barrister involved in proceeding (Morning of 24 February 2015, Melbourne) ('Interview with barrister $A^{\prime}$ ).

67 Interview with Justice J Forrest, above n 49.

68 Ibid.
} 
While the parties understood the assessors were not sitting in a judicial role, Associate Justice Zammit said that the experts giving evidence "struggled" with it, seeing them almost as equal to the Judge. 69

Most of the external participants all saw value in the appointment of assessors in the proceeding. The legal practitioners expressed some relief that Justice Forrest had access to experts to assist him understand the evidence the other experts were putting before the Court. One solicitor said that it was "necessary" to have assessors as it was "really hard for any single person to get on top of the vast range of disciplines that were at stake"..$^{70}$ He said that while his party had "some confidence in [their] scientific thesis" they worried about a "persuasive scientist" who managed to convince the Court to accept contrary evidence. He said they had "great confidence that the more qualified the scientific mind assisting the court, the better the process [would work]." 71 The other solicitor said they were "of benefit to the trial."72

One barrister said that the presence of assessors helped the Court stay on topic:

[...] having [assessors] who were acknowledged experts in the relevant fields was a superbly effective way of cutting through the verbiage, cutting through the bullshit, and reassuring the parties that the judge was going to be able to understand evidence that was beyond PhD levels of sophistication. ${ }^{73}$

The other barrister said that using assessors in highly technical or scientific cases was "a very useful idea" that "can only be of advantage to a judge." 74 He said that assessors were "essential" for parts of the expert evidence in the Kilmore East bushfire proceeding as this evidence was extremely complex quantitative science, heavily reliant on sophisticated mathematical modelling. ${ }^{75}$ It does, however, depend on the nature of the expert evidence: he noted that Justice Forrest was able to sit without assessors for the more straightforward areas of expert evidence. ${ }^{76}$

The experts also supported the role of the assessors in the proceeding. One said that he thought they were "great" and "both clever and lively and well over the subject material". ${ }^{77}$ Perhaps more

\footnotetext{
${ }^{69}$ Interview with Associate Justice Zammit, above n 46.

${ }^{70}$ Interview with solicitor A, above n 59.

71 Ibid.

72 Interview with solicitor B, above n 60 .

${ }^{73}$ Interview with barrister A, above n 66.

${ }^{74}$ Interview with barrister B, above n 61 .

75 Ibid.

76 Ibid.

77 Interview with expert (24 March 2015, by email) ('Interview with expert B').
} 
problematically, his view was that they "quickly put together the arguments and had their own theories on most topics we covered". ${ }^{78}$ He said that:

My own view is that having these people sitting next to the Justice was a very clever strategy designed to do justice, and prevent gobbledygook tech-talk from bamboozling the court. It prevented or reduced my own enthusiasm to push the QC into a technical field as a means of defence, and encouraged me to answer the question with technical accuracy knowing that the Justice would have the answer explained if required. ${ }^{79}$

He said that the assessors provided "a vector for technical communication", and that "[s]everal of [his] own answers to questions during cross-examination, or in statements within the section summaries were directed at the Justice via the assessors." 80 It was possible to have "gloves-off technical dialogue." 81 He saw considerable value in being able to provide "dense specific technical dialogue" to the Court and have it understood, but that not all experts exploited this possibility. ${ }^{82}$

The other expert was more circumspect. He acknowledged that they "probably helped the judge a great deal", but questioned whether they had the appropriate qualifications, saying "the science of the vibration of conductors, which was central to the failure, was outside their expertise." 83 He said that while they were "well grounded in engineering and physics", they "showed no experience of the procedures and functions of an electrical utility" and that they lacked industry experience. ${ }^{84} \mathrm{He}$ said that they shared this inexperience with many of the other experts. ${ }^{85}$

\section{Assessors and the expert conferences}

The assessors drafted questions on the critical issues for the experts in one of the larger expert conferences to answer at the conclusion of the conference. ${ }^{86}$ Associate Justice Zammit said that while the summary of expert opinion this produced was helpful, the process adopted did not give enough warning to the experts that they would have to do the task at the end of the conclave. She explained:

\footnotetext{
78 Ibid.

${ }^{79}$ Ibid.

80 Ibid.

81 Ibid.

82 Ibid.

${ }^{83}$ Ibid.

${ }^{84}$ Interview with expert (23 February 2015, by email) ('Interview with expert A').

85 Ibid.

${ }^{86}$ Interview with Associate Justice Zammit, above n 46.
} 
The experts I think were pretty put out that $[\ldots]$ they were suddenly asked to do things individually again without any real notice. They thought the questions were [too simplistic], and it may have just been $[\ldots]$ that they were exhausted. Again, [...] in hindsight it would have been [better] to forewarn them that at the end [of the conclave] they would be asked to spend a day on their own with a set of questions. ${ }^{87}$

This shows the importance of properly explaining to the experts what is expected of them during the process. It also suggests that the earlier appointment of assessors could be helpful in providing a framework for the expert conferences.

\section{Interaction between the assessors, the Court and the parties}

The assessors worked very closely with Justice Forrest for the month that the relevant expert evidence was presented to the Court. Justice Forrest said the assessors "effectively lived with me" during this period, and had desks in his chambers. ${ }^{88}$ The main limit he placed on their interactions with him and the Court was the request they not ask questions about topics not raised in the expert reports. ${ }^{89}$ He said that this was sometimes difficult as the assessors had particular views about aspects of the evidence not canvassed in the expert reports. ${ }^{90}$ During the concurrent evidence session, he had to consider carefully whether each question asked by the assessors should be allowed, because he needed to ensure the assessors did not go outside the scope of the pleadings in the case or the expert reports. He said, however, that this caused no major difficulties. ${ }^{91}$

The legal practitioners thought the extent of the assessors' involvement in the proceeding, and the limits placed on their interaction with the judge, were appropriate. One solicitor said he had "no complaint", and that he could "tell from what their question was what their area of interest was, and it generally seemed to be about right." 92 He said he "didn't perceive there to be a strong limit" on their interaction with the experts, so they were able to follow up with questions if "they were unsatisfied as to something", and that this "was appropriate." 93

\footnotetext{
87 Ibid.

${ }^{88}$ Interview with Justice J Forrest, above n 49.

89 Ibid.

90 Ibid.

${ }^{91}$ Interview with Justice J Forrest, above n 58.

92 Interview with solicitor A, above n 59.

93 Ibid.
} 
He thought having the assessors asking questions of experts was "useful" as it was "an indication to us of what issues they thought were important [...] to understand the expert's view fully." $94 \mathrm{He}$ went on to say that the questions asked made it "obvious" that one assessor was more across the material than the other, saying this assessor "understood the points, and knew exactly where were the soft points in someone's case or the strong points". ${ }^{95}$ He said that he "wouldn't say the other didn't understand", it was just that it was particularly obvious that one assessor had mastered the expert material. ${ }^{96}$ Nevertheless, he said that his party "actually got confidence through the process and the questions that they fully understood what was being said" and that this was "helpful." 97

The other solicitor said that the limitations on the assessors' role were "appropriate." He said the safeguard in the relevant ruling requiring the Court to discuss with counsel if the assessor "raised a theory or opinion that had not previously been identified by the parties" was particularly important "[g]iven the leading expertise of the appointed assessors." 98

One of the barristers said a judge could use assessors for "a whole host of reasons": to give "the judge a primer in the science beforehand"; to talk with the judge about questions to ask the experts during concurrent evidence sessions; to give separate advice on the evidence; or even to "assist with the draft judgment". ${ }^{99}$ He said that the critical thing was that there was transparency with the parties, and ensuring there was no delegation of judicial power. ${ }^{100}$ Referring specifically to the assessors in the Kilmore East bushfire proceeding, he said their "actual performance [...] was very good". He explained:

They were sitting there, they listened, they were allowed to ask questions, I thought their questions were very well targeted - particularly [one assessor] - and I thought that was very useful, and also just the sheer presence of two assessors there disciplined the experts. Even if they thought they could put it over counsel or the judge, if you have a professor on [both] side[s] of the judge, [...] and you're an expert, you're less likely to say something that you think you can get away with that's pretty dodgy, [as] you're going to be picked up and made to look like an idiot. So I thought the assessors here were actually good in disciplining the performance of the expert witnesses in the concurrent evidence session. ${ }^{101}$

\footnotetext{
${ }^{94}$ Ibid.

95 Ibid.

96 Ibid.

${ }^{97}$ Ibid.

${ }^{98}$ Interview with solicitor B, above $\mathrm{n} 60$.

${ }^{99}$ Interview with barrister B, above $\mathrm{n} 61$.

100 Ibid.

${ }^{101}$ Ibid.
} 
He said it was not necessary for Justice Forrest to reveal the advice he was given by the assessors, but noted it would have been appropriate if it had been about material that had not been the subject of evidence or had not been raised in front of the parties. $102 \mathrm{He}$ said it was understood by the parties that the assessors were there to "assist the judge to understand the evidence as it [...] unfolded", and that this was appropriate. ${ }^{103}$ He explained that strict controls were not necessary and it was better just to "trust the judge a little bit." He said it is important for the judge to disclose in broad terms what role the assessors will be playing in the judge's chambers and in the judgment writing process, but the parties "don't have to know chapter and verse of what the assessor has said to the judge behind closed doors." He said that:

[...] I don't see difficulty in a judge saying to an expert behind the scenes saying the concurrent evidence session is over, "look I didn't quite understand how the Strouhal number fits into the sequence of Aeolian vibration, can you just take me through that formula again?" - that's not something I would expect a judge would need to disclose. ${ }^{104}$

He said that this was not unlike judges informally speaking with other judges or their associates to "road test a particular proposition". He said "as long as the judge is not taking into account something the parties have never had an opportunity to answer" there was no difficulty in the assessors providing assistance. ${ }^{105}$

One expert said the "assessors befriended people who demonstrated technical capacity," and that "their frustration at questioning people who misinterpreted the question, or couldn't answer a question on notice, was obvious." $106 \mathrm{He}$ also said that the assessors, somewhat problematically, showed an "enthusiasm to follow their own pet argument or interpretation of the data." 107 He said that this seemed to "overstep their duty and put them in a position where their argument [...] needed to be cross-examined, or questioned." 108 The expert said that he was unwilling to do this as "when [...] [it] occurred it felt like I would appear to be picking a fight with the Justice, something I was told not to do." 109 He said, however, that he was "saved from this by the Justice who stopped the [assessor asking] questions" and moved the proceeding along. ${ }^{110}$

\footnotetext{
102 Ibid.

103 Ibid.

104 Ibid.

105 Ibid.

106 Interview with expert B, above $n 77$.

107 Ibid.

108 Ibid.

109 Ibid.

110 Ibid.
} 


\section{E. Abdication of judicial power}

Justice Forrest did not accept that the appointment of assessors placed him at risk of an abdication of judicial power. He said that after his experience in the Kilmore East bushfire proceeding, he remained convinced that the appointment of assessors was valuable:

[...] whilst there is a criticism that the assessors have too much or may have too much nontransparent influence on the judge, the judge is well aware [...] that it is his or her decision alone, whatever the assessors might say, and that the assessors' role is simply to assist in the evaluation of the expert evidence.

[...] If assessors were not appointed I would have blundered through the expert evidence and I think at one point of time or at least a number of points of time would simply be incapable of understanding the concepts being advanced by the experts. And it's all very well to talk about transparency; it's fundamental that the parties get a just result. And if they have a judicial officer that doesn't understand the arguments that they are making on factual issues then they will not get a just result. So I reject emphatically the idea that assessors should not be used or should not be part of the judicial process. On the other hand, I think it's important to bear in mind that it is the judge's role alone to determine the evaluation of the expert evidence. ${ }^{111}$

Justice Forrest said he was careful to provide the assessors with guidance about their procedural and substantive role in the trial, giving them copies of the various rulings and explaining on multiple occasions the limitations of their role. He said that they were "able to follow without any real encouragement or further clarification the different roles we all fulfilled". 112 This is a prudent approach: the assessors will have opinions about what evidence should be accepted, but the judge should be careful to ensure they understand their role is not to decide the case, but to assist the judge.

None of the other participants viewed the use of the assessors as an abdication of judicial power. One solicitor said that it was "nonsense" that the appointment of the assessors would be an abdication of judicial power. ${ }^{113}$ The other solicitor said it was "completely appropriate that assessors were involved in this proceeding." 114 He said that the role of the assessors in assisting the judge was clear to the parties. He said their presence ensured that "having heard all this evidence [Justice Forrest] assimilated it correctly and understood it" and was weighting evidence appropriately, appreciating when a particular issue was determinative or "simply a consideration

\footnotetext{
111 Interview with Justice J Forrest, above n 58.

112 Ibid.

113 Interview with solicitor A, above n 59 .

114 Interview with solicitor B, above n 60 .
} 
amongst the vast number of considerations to take into account in working out what had happened."115 The solicitor "never had any sense the judge would simply be applying someone else's views."116

Similarly, one barrister said that he "never had any concern that Justice Forrest was going to be dictated to by anybody, an assessor or anyone else." He said that with a "highly experienced, highly regarded judge who we know was trying to do the best he could in the case", he trusted the process. He said he "understood that the assessors were there to listen to the evidence and be in a position to discuss with the judge" and that he considered this was "a sensible solution to a really difficult problem." 117 The other barrister agreed, saying it is a "nonsense argument" that the judge was abdicating judicial power; in this case there was no doubt that "ultimately it [was] for the judge to make the decision." 118 As long as the way in which the judge informed himself was transparent and consistent with procedural fairness to the parties, it was not a real issue. ${ }^{119}$

\section{CONCLUDING REMARKS}

The appointment of assessors in the Kilmore East bushfire proceeding appears to have been a success. All the participants interviewed, and particularly Justice Forrest, regarded them as being beneficial to the trial. The assistance they provided Justice Forrest in understanding the expert evidence coming from the most scientifically complex expert conference was essential. The suggestion that assessors be appointed earlier in the proceeding to help plan the expert conferences may be worth considering in cases of similar complexity in the future.

The assessor selection process adopted by Associate Justice Zammit worked well in this case. Requiring the parties to produce the list of candidates and then make submissions on which to appoint ensures the parties have input into this decision. Her Honour recognised that she would have found it very difficult to put together a list herself, and that the parties were much better placed to make an assessment of who were the leading scholars in the field. In addition, including assessors from the two different professional backgrounds represented in the relevant expert conference was an appropriate way of ensuring the advice received by Justice Forrest was balanced and comprehensive.

\footnotetext{
115 Interview with solicitor A, above n 59.

116 Ibid.

117 Interview with barrister A, above n 66.

118 Interview with barrister B, above n 61 .

119 Ibid.
} 
The order made by Justice Forrest defining the role of the assessors set appropriate limits. The barristers expressed relief that there were experts sitting as assessors alongside the Judge to ensure that he properly understood the evidence. Similarly, the experts said the ability to engage in a technical dialogue before the Court made providing accurate evidence easier. The experts picked up that one assessor had a pet theory that he was trying to put before the court, but this seems to have been adequately dealt with by Justice Forrest.

None of the participants thought that the appointment of assessors in this case amounted to an abdication of judicial power. This was despite the parties not knowing everything the assessors and Justice Forrest discussed, nor what conclusions the assessors reached about certain issues. As noted by one of the barristers, requiring disclosures of this kind would have made it much more difficult for the assessors to provide the kind of on-the-spot advice the judge sometimes needs as he or she is working through the expert evidence produced to the Court. It is clear that a seminar prior to the commencement of the trial would not have been nearly as useful to Justice Forrest in working through and understanding the expert evidence.

It is important to recognise a crucial limitation of using this case as an example: it was settled prior to a final decision being handed down. It is possible that if one of the parties or their experts had detected that the conclusions of Justice Forrest in a final judgment were derived from one of the assessors, they would have been much less positive about the use of assessors. Notwithstanding this limitation, the Kilmore East bushfire proceeding suggests that the use of assessors can be valuable in cases dealing with highly complex expert evidence. 


\section{APPENDIX}

\section{A. Section One: View from the Victorian bench}

The judges interviewed who were not involved in the Kilmore East bushfire proceeding did not have any experience with the use of assessors in civil trials. They thought assessors could be useful in some cases, but that it was critical for the role of the assessor to be fully explained to the parties with the limits of any interaction between the judge and the assessor made clear.

Justice Almond said he had never used an assessor, but that he did not have any "philosophical objection to the use of them." He said they could be particularly useful for cases like the Kilmore East bushfire proceeding that are of a "different order of magnitude altogether" and are "highly technical."120 Justice Croft said that he had not used an assessor either, but that he would certainly contemplate it after some difficult experiences with cost determinations. ${ }^{121}$ He said that it could be "very, very useful" in managing concurrent evidence and help fill any gaps in the judge's knowledge of the evidence.

Justice Hargrave said he understood assessors just sit with the judge so the judge can consult with them, and that their "role in the judge's final reasons will be unknown." 122 It was a much more sensible option than having the parties called back in every time the judge confronted a problem in writing the judgment with understanding the expert evidence, which would substantially increase the cost and time the proceedings would take. ${ }^{123}$

Justice Croft noted that the appointment of assessors would be "very tricky." It would be necessary to be "very careful how that process is handled" and the "parties must know very clearly what the role of the assessor is." 124

\section{Distinction between Assessors and Special Referees}

Justice Hargrave said that assessors and special referees could both assist the Court, but that they served different needs:

It depends on how large the reference is, I suppose. If it's purely technical, and the disputed facts relate to the expertise of the special referee, I see no reason why they can't determine the facts.

\footnotetext{
120 Interview with Justice Almond (13 October 2014, Supreme Court of Victoria, Melbourne).

121 Interview with Justice Croft (14 October 2014, Supreme Court of Victoria, Melbourne).

122 Interview with Justice Hargrave (6 October 2014, Supreme Court of Victoria, Melbourne).

123 Ibid.

124 Interview with Justice Croft (14 October 2014, Supreme Court of Victoria, Melbourne).
} 
They're much better at doing that and the court's not bound to accept the referee's report. If there are critical facts which are bound up with the credit of the witnesses who are giving evidence at the main trial, then assessors are a really good idea to sit there and help the judge and when he or she comes to decide that factual issue. ${ }^{125}$

He said that parties were normally happy to have specific factual matters sent to a special referee or court-appointed expert as long as it was appropriate to the facts in the case and the process fully explained. ${ }^{126}$ Special referees or court appointed experts are particularly useful where, for instance, there is a significant amount of accounting calculations but the underlying facts have been determined. ${ }^{127}$ He said this is much more efficient and can save the parties money. ${ }^{128}$

\section{Assessors as an abdication of judicial power}

The judges did not consider that using an assessor was necessarily an abdication of judicial power. Justice Almond was not convinced there was a risk as long as the assessor has a "confined role" to assess on a particular aspect of the case. ${ }^{129}$ Justice Croft said that while the parties may be concerned about the risk of delegation of judicial authority, in the end they will have to trust the Court that the "internal processes" are appropriate. ${ }^{130}$ His Honour likened it to the role that associates and researchers can play in assisting judges in the judicial process:

How far do you need to go with the case summaries or submission summaries, drafts of bits of judgments before you say, "Aha, you've crossed the line. In fact, you're not actually deciding this; you've delegated the function". Now, I think as long as everyone's aware of the potential problem, and that you really do read the evidence, and read the cases and direct your mind to it as a judge, and you sign off on it, you can't seriously say it's an abdication of the judicial function. [This is particularly] having regard to the massive resources that litigants have with law firms [...], you have one judge "versus" hundreds of people from two major law firms delivering material. [It is necessary to] be a bit sensible. ${ }^{131}$

Similarly, Justice Hargrave said that the appointment of an assessor is not an abdication of responsibility. ${ }^{132}$ It is something that can assist the judge to deal with very complex evidence.

\footnotetext{
125 Interview with Justice Hargrave (6 October 2014, Supreme Court of Victoria, Melbourne).

126 Ibid.

127 Ibid.

128 Ibid.

${ }^{129}$ Interview with Justice Almond (13 October 2014, Supreme Court of Victoria, Melbourne).

130 Interview with Justice Croft (14 October 2014, Supreme Court of Victoria, Melbourne).

131 Interview with Justice Almond (13 October 2014, Supreme Court of Victoria, Melbourne).

132 Interview with Justice Hargrave (6 October 2014, Supreme Court of Victoria, Melbourne).
} 


\section{B. Section Two: Methodology}

The material for this research project was gathered in interviews with judges of the Supreme Court of Victoria and some of the participants of the Kilmore East bushfire proceeding. The interviews were conducted in late 2014 and early 2015 in person and by email and letter. The judges selected included Justice Forrest and Associate Justice Zammit (as she then was), who presided over parts of the proceeding, and other judges, who were chosen as they were thought to represent a range of different views about the management of expert evidence (Justice Beach, Justice Croft, Justice Almond and Justice Hargrave). The participants of the Kilmore East bushfire proceeding who were interviewed were selected to ensure that the research took account of both the plaintiff and defendant sides, as well as covering the different roles within the proceeding. To this end, two barristers, two solicitors and two experts were interviewed. They agreed to be interviewed on the basis that they would remain anonymous due to the sensitive nature of some of their comments, and so all identifying information has been removed from their answers.

Interviews in person were semi-structured and the questions were both broad (e.g. "What are your views on the use of assessors in the trial?") and focussed (e.g. "What are your views on the method of selection of the assessors?"). Interviews conducted by email or letter were written responses to the same questions asked in the in-person interviews. The research project has some obvious limitations: it was not feasible to interview all the judges of the Supreme Court or all the participants in the Kilmore East bushfire proceeding. It does not in any way assess the experience of the many plaintiffs, whose tragic experiences were the basis of the case. This paper is not intended to be a source of comprehensive empirical data. Rather, it aims to ensure the experience of the court during these significant proceedings is recorded and that any lessons that were learnt during the proceeding are captured for posterity. It is hoped that this record will be of value to other judges of the Supreme Court of Victoria, as well as judges in other jurisdictions and legal practitioners. One of the aims of the project was to better understand how less common methods

of managing expert evidence were used by the court and perceived by participants - and the Kilmore East bushfire proceeding represents an excellent opportunity to assess some of these matters. 


\section{University Library}

\section{- M M I E R R A A gateway to Melbourne's research publications}

Minerva Access is the Institutional Repository of The University of Melbourne

Author/s:

McKenzie, S

Title:

Assessors in the Kilmore East bushfire proceeding

Date:

2016-04-13

Citation:

McKenzie, S. (2016). Assessors in the Kilmore East bushfire proceeding. Supreme Court of Victoria.

Persistent Link:

http://hdl.handle.net/11343/91569 